\title{
The Importance of Measuring Erosion Processes on the Example of Slovenia
}

\author{
Matija Zorn, Blaž Komac
}

\begin{abstract}
This article examines soil erosion and erosion processes in badlands and presents the necessity and importance of their research. We present our findings regarding measurements of erosion processes that we carried out in a flysch region in the Dragonja River Basin in southwest Slovenia and in a dolomite region in central Slovenia in the Polhov Gradec Hills. Soil erosion was measured for various land-use types: an olive grove, a meadow, and a forest. Special emphasis was placed on interrill erosion, which is almost imperceptible without measurement. The measurement results served as a foundation for the importance of studying erosion processes as well as various applied aspects such as obtaining data for verification of erosion models, estimating damage caused by erosion, raising risk awareness due to erosion hazard, and improving coastal management.
\end{abstract}

Key words: soil erosion, badlands, geomorphic processes, Slovenia

\section{Važnost mjerenja erozije na primjeru Slovenije}

U radu se istražuju erozija tla i erozijski procesi u ogolinama te se prezentira potreba i važnost takvih istraživanja. Predstavljena su istraživanja povezana s mjerenjima erozijskih procesa u flišnoj regiji u dolini rijeke Dragonje u jugozapadnoj Sloveniji te u dolomitnoj regiji u srednjoj Sloveniji, u Polhograjskim brdima. Eroziju tla mjerilo se kod različitih načina iskorištavanja zemljišta: maslinik, livada i šuma. Naglasak je stavljen na plošnu eroziju koja je gotovo nevidljiva bez mjerenja. Rezultati mjerenja poslužili su kao osnova važnosti proučavanja erozijskih procesa kao i za razne primjenjive aspekte poput pribavljanja podataka za verifikaciju erozijskih modela, procjenu štete nastale erozijom, podizanje svijesti o razini rizika uslijed erozije te pri upravljanju priobaljem.

Ključne riječi: erozija tla, ogoline, geomorfološki procesi, Slovenija 


\section{INTRODUCTION}

"Commonly speaking the term erosion (from Latin erodere = to gnaw away) is often used to indicate the overall exogenic processes or group of processes that are directed at levelling off Earth relief" (Lupia-Palmieri, 2004, 331). Among the many processes that are understood within this concept, this article focuses on soil erosion and erosion processes in badlands. Based on this, we present the necessity and significance of studying these phenomena.

In Slovenia in the past decade, there has been intensive study of erosion processes in non-limestone areas, especially in order to understand better the geomorphic system in these areas because these areas were neglected in this regard in the past. It turned out that the findings are not only important for theoretical geomorphology, but that they also have applied value; for example, to gain data for verification of erosion models, to estimate damage caused by erosion, or to raise risk awareness of erosion hazard, to name only those that are focused on below. This also represents a step toward applied geomorphology in Slovenia in regard to studying erosion processes. We have written more about applied geomorphology itself in this volume of the journal in the article "Applied Landslide Geomorphology - some Examples from Slovenia.”

\section{Soil erosion}

\section{METHODS}

Soil erosion measurements were carried out between 2005 and 2008 (Zorn, 2008, 2009a; Petan 2010) on flysch soil near the village of Marezige in the Rokava River Basin (a right tributary of the Dragonja River) in south-western Slovenia. We measured

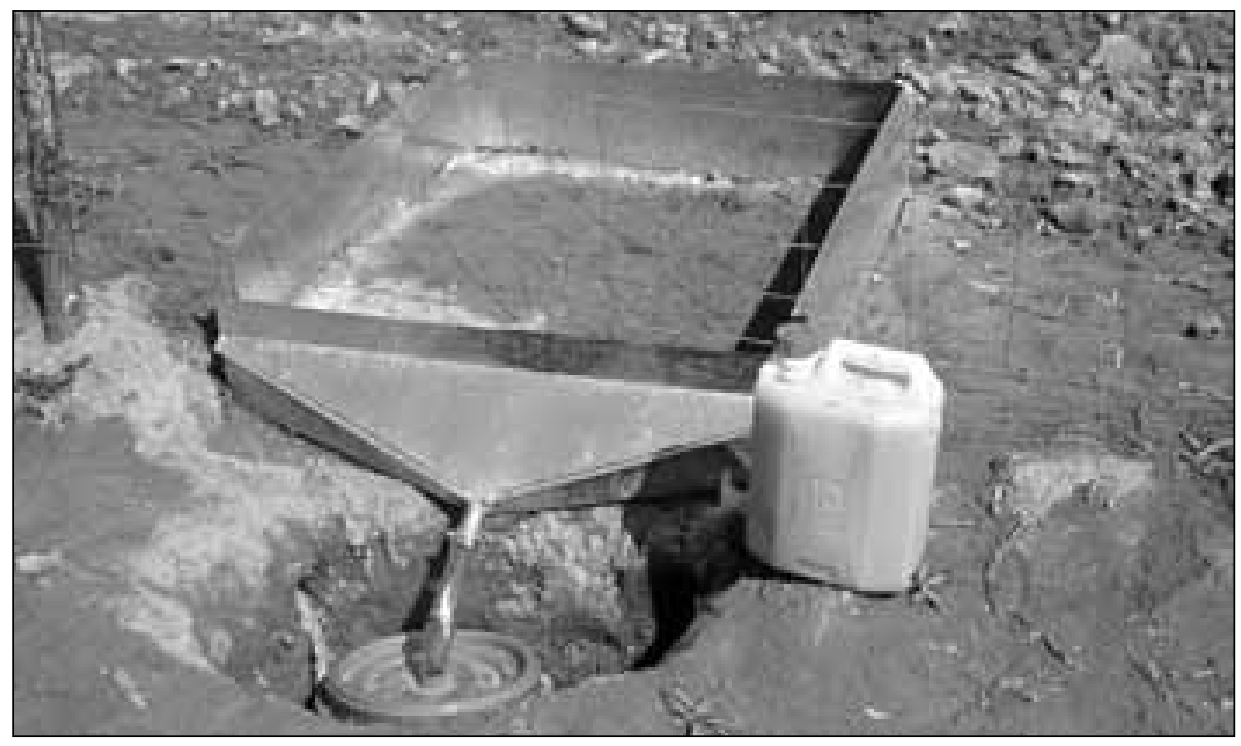

Fig. 1 One-meter-square closed erosion plot for measuring interrill soil erosion on bare soil Sl. 1. Zatvorena parcela površine $1 \mathrm{~m}^{2}$ za mjerenje plošne erozije na golom tlu 
interrill erosion and rill erosion. Interrill erosion was measured using one-meter-square closed erosion plots in three different land-use areas: bare soil in an olive grove (with an inclination of $5.5^{\circ}$; Fig. 1), an overgrown meadow (with an inclination of $9.4^{\circ}$ ), and a forest (with inclinations of $7.8^{\circ}$ and $21.4^{\circ}$ ). Similar measurements in a flysch area, but on somewhat larger erosion plots, were carried out at the same time at Abrami, Croatia, only a few dozen kilometres away (Petraš et al., 2008).

Every week we collected samples from the erosion plots. At the laboratory we measured the amount of water in the collecting containers to obtain the weekly surface runoff. From smaller representative samples we quantified suspended (insoluble) material according to the DIN 38409-H2 standard. The samples were dried at a temperature between $103^{\circ} \mathrm{C}$ and $105^{\circ} \mathrm{C}$.

In addition to systematic measures of interrill erosion, we also carried out periodic measurements of rill erosion. Erosion rills were measured with detailed geomorphological mapping; cross-sections of rills were measured every $10 \mathrm{~m}$. The measurements were taken after major precipitation events, when erosion rills appeared on bare soil (Fig. 2).

\section{Geomorphic processes in badlands}

Measurements of erosion processes in badlands were taken in flysch areas in southwestern Slovenia (Zorn, 2008, 2009b), not far from measurements of soil erosion, and in

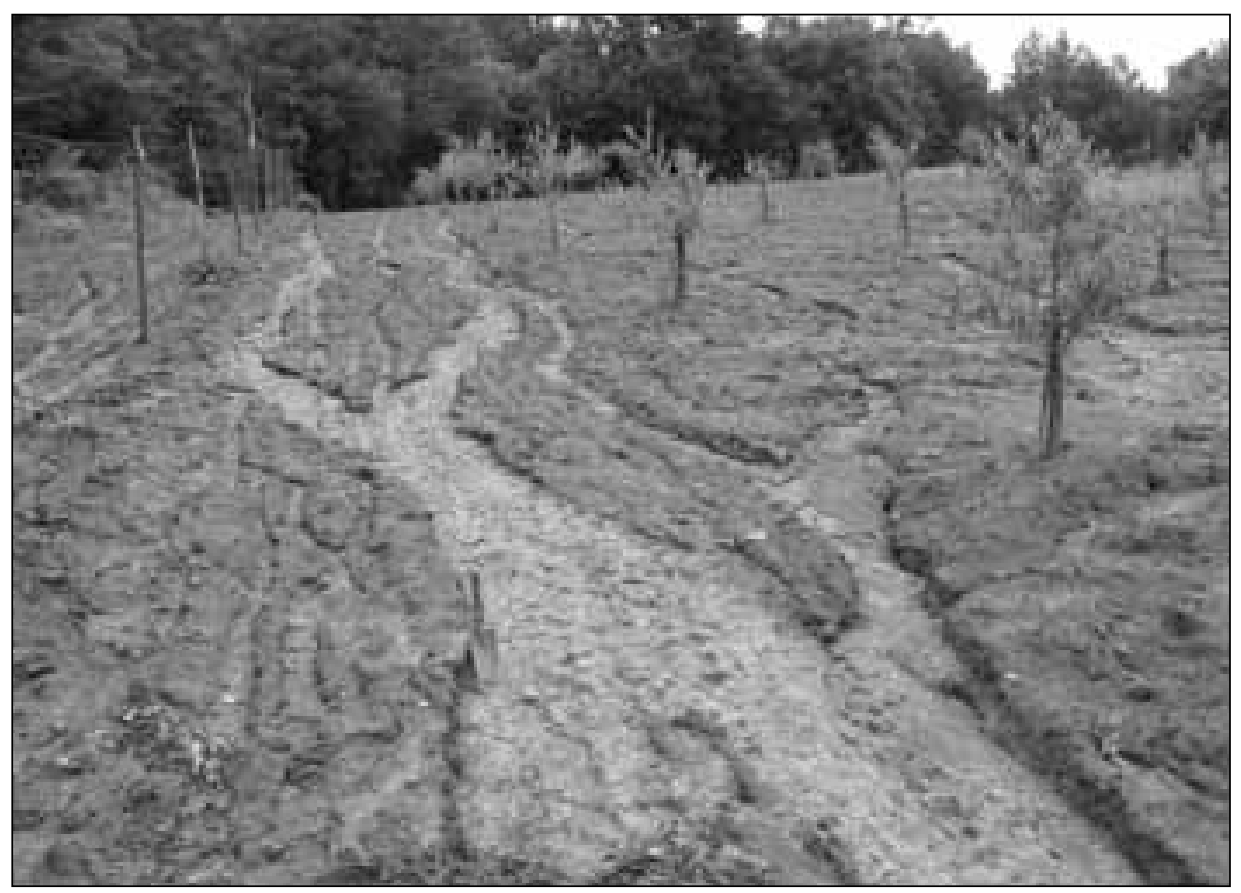

Fig. 2 Erosion rill that occurred during intensive precipitation in August 2005

Sl. 2. Brazdasta erozija za vrijeme intenzivnih padalina u kolovozu 2005. 


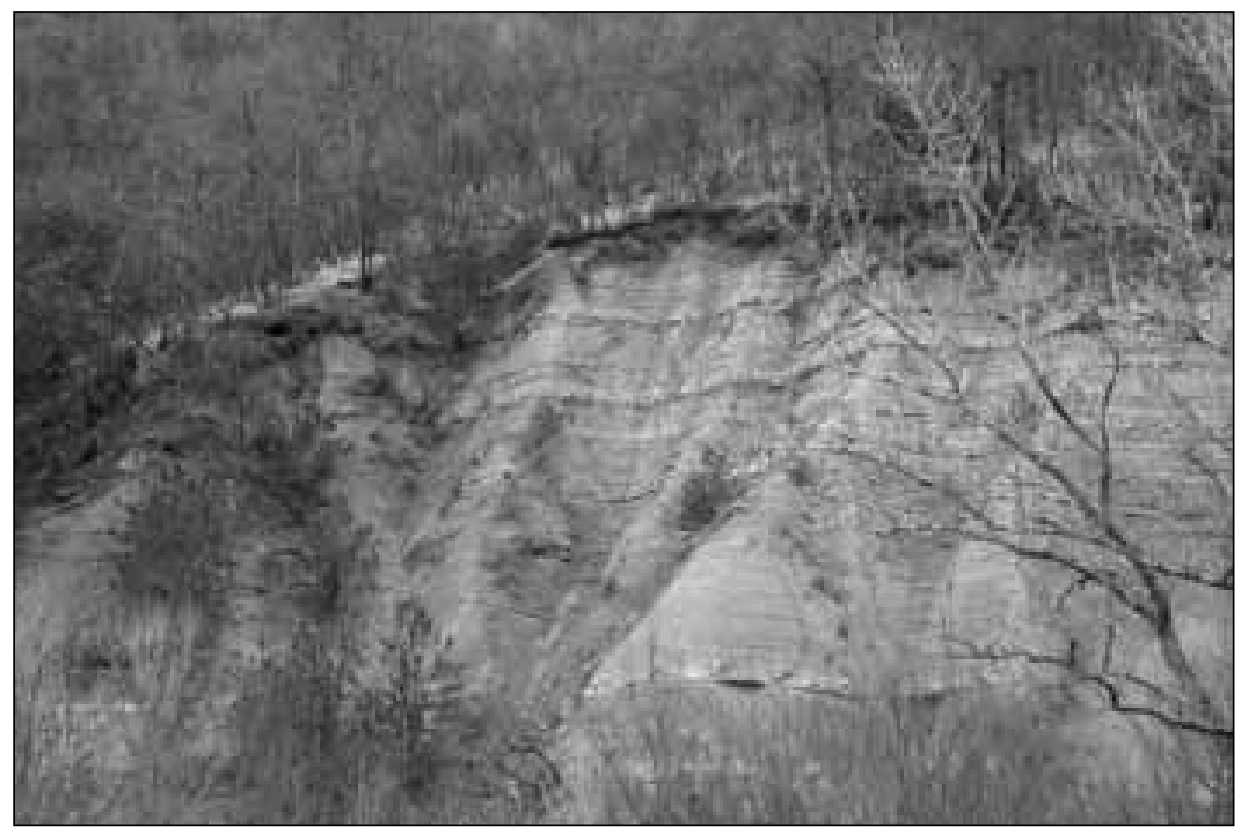

Fig. 3 Flysch badlands where measurements were taken (Rokava River Basin, Slovenian Istria) Sl. 3. Ogoline u flišu, lokacija provedbe mjerenja (dolina rijeke Rokave, Slovenska Istra)

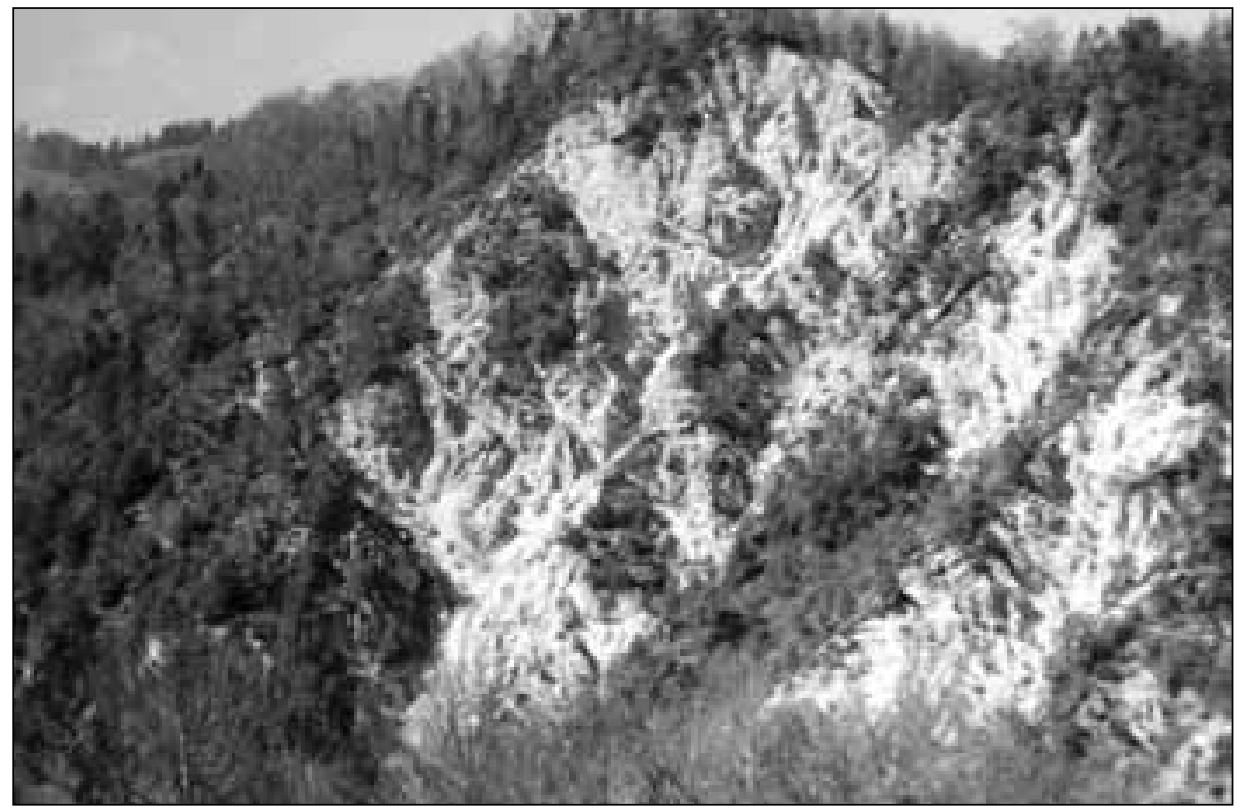

Fig. 4 Dolomite badlands where measurements were taken (Polhov Gradec Hills)

Sl. 4. Ogoline oblikovane na dolomitu, lokacija provedbe mjerenja (Polhograjska brda) 


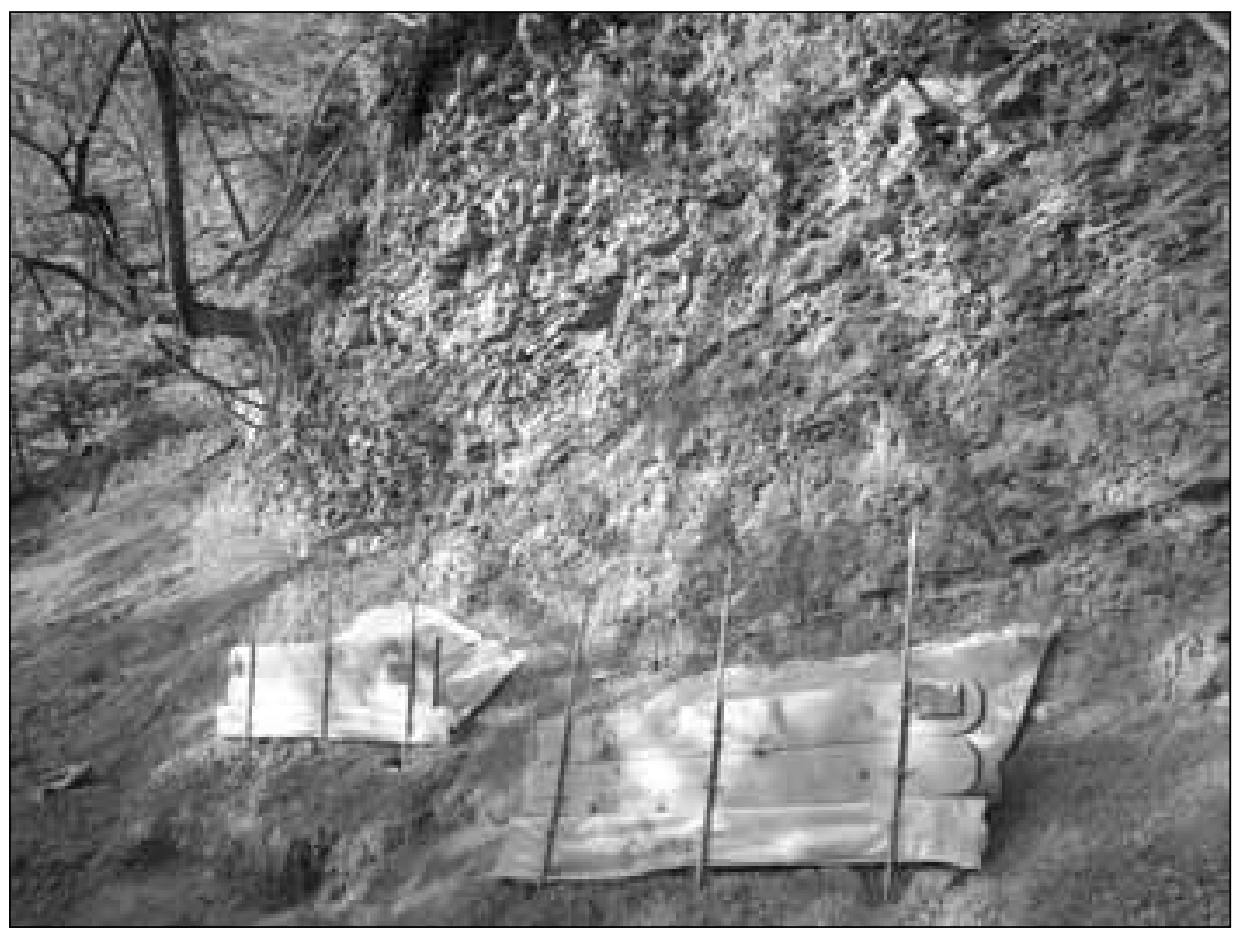

Fig. 5 Semi-open erosion plots for measuring sediment production

Sl. 5. Poluotvorene erozijske parcele za mjerenje količine novonastalog sedimenta

a dolomite area in central Slovenia in the Polhov Gradec Hills (Komac, 2003). Measurements included (1) sediment production from steep bare slopes (rockwall retreat) and (2) movements of debris along erosion gullies. The measurements in the flysch badlands (Fig. 3) were taken in 2005 and 2006 and in the dolomite badlands (Fig. 4) in 2002 and 2003.

We measured the sediment production from steep bare (Eocene) flysch slopes using semi-open erosion plots (Fig. 5). The upper sides of the erosion plots were bordered by the edge of a badlands, and their sides were open. We collected the material behind the barriers on a weekly basis and dried and weighed it in the laboratory.

The steep bare slopes of the badlands include not only rock walls with a $70^{\circ}$ to $90^{\circ}$ inclination, but also slopes with $40^{\circ}$ to $60^{\circ}$ inclinations already eroded by erosion rills and gullies.

Unlike interrill soil erosion and rill soil erosion, where material is mostly deposited on the slope itself or at its base, gully erosion offers more opportunities for eroded material to reach watercourses at the bottom of valleys. Erosion gullies are thus a very important source of eroded material (Poesen and Hooke, 1997).

For our measurements we constructed barriers in erosion gullies (Figs. 6 and 7) and took measurements on a weekly basis in flysch badlands and on a post-event basis in dolomite badlands. The material was dried and weighed with an electronic scale. 
Hrvatski geografski glasnik 73/2 (2011.)

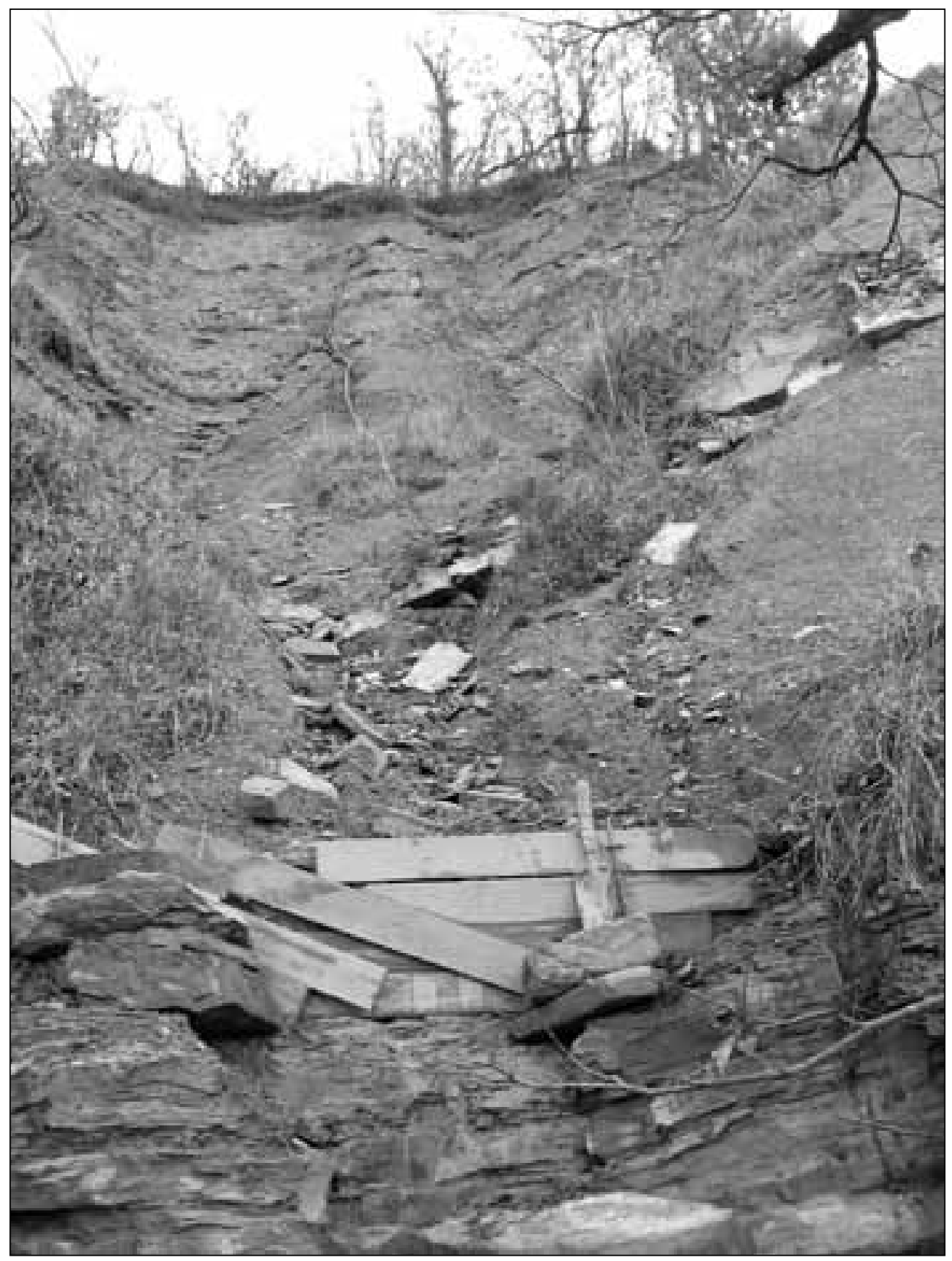

Fig. 6 Barrier in a flysch erosion gully

Sl. 6. Prepreka u jaruzi oblikovanoj u flišu 


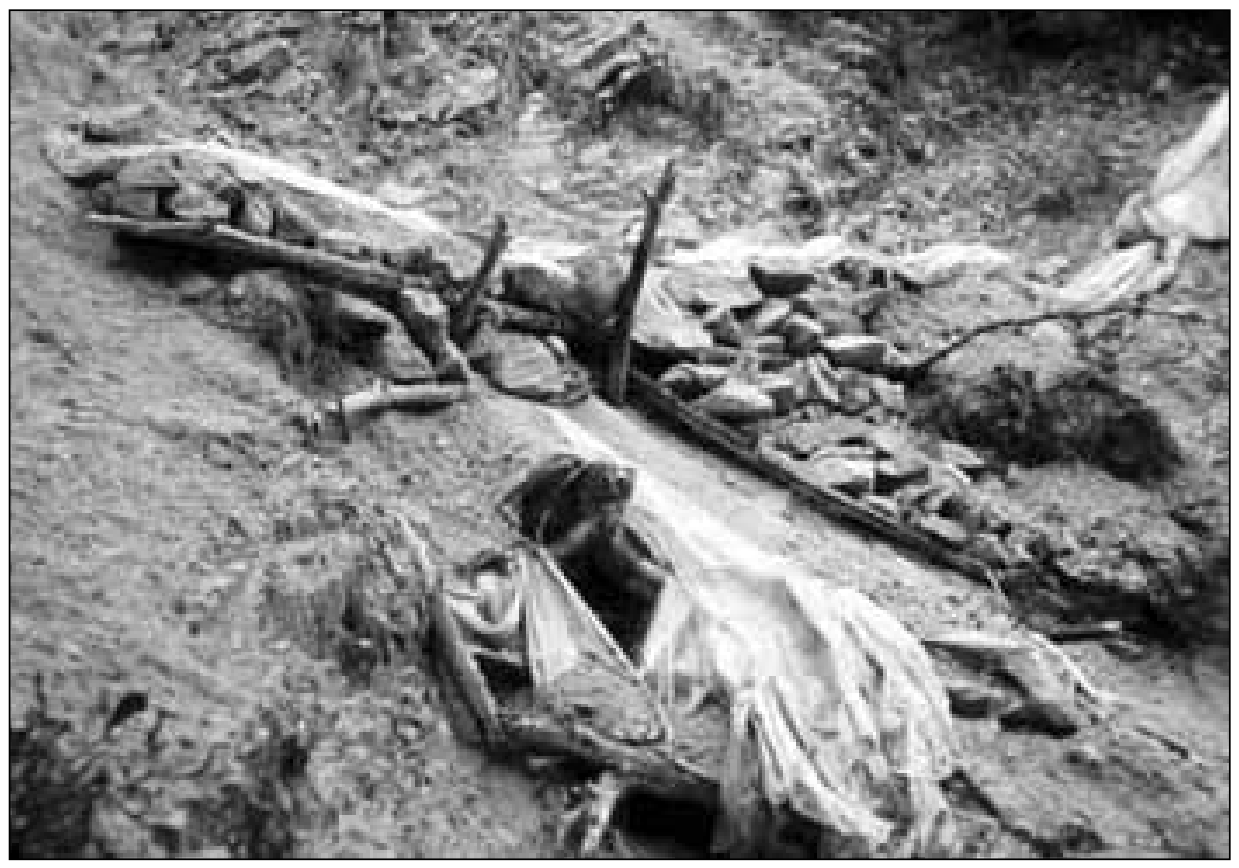

Fig. 7 Barrier in a dolomite erosion gully

Sl. 7. Prepreka u jaruzi oblikovanoj u dolomitu

\section{Soil erosion}

\section{MEASUREMENT RESULTS}

Interrill soil erosion was greatest by far on bare soil in an olive grove (Tab. 1). Soil erosion in the forest with a greater inclination in the first measurement period followed, and third place went to the forest with a lower inclination. The least soil was eroded on the overgrown meadow, which is not surprising given the dense vegetation inside the plots.

In the second measurement period, there were problems with the measuring equipment in the forest with a greater incline, and so a low number is cited in Tab. 1. This is because it was difficult properly to install the funnel of the erosion plot in the ground in the greater inclination area, which resulted in the loss of a significant amount of surface runoff and eroded material under the funnel during this measurement period.

Tab. 1 Interrill erosion (t/ha per year) on flysch soil in southwest Slovenia (Zorn, 2009a, 46-49; Petan, 2010, 188) Tab. 1. Plošna erozija (t/ha godišnje) na flišnom tlu ujugozapadnoj Sloveniji (Zorn, 2009a, 46-49; Petan, 2010, 188)

\begin{tabular}{|l|c|c|c|c|}
\hline \multicolumn{1}{|c|}{ Measurement period } & $\begin{array}{c}\text { Bare soil in an } \\
\text { olive grove }\end{array}$ & $\begin{array}{c}\text { Overgrown } \\
\text { meadow }\end{array}$ & $\begin{array}{c}\text { Forest (lower } \\
\text { inclination) }\end{array}$ & $\begin{array}{c}\text { Forest (greater } \\
\text { inclination) }\end{array}$ \\
\hline 1) April 2005-April 2006 & 94.1 & 1.8 & 4.1 & 4.6 \\
\hline 2) August 2006-August 2008 & 112.5 & 0.75 & 3.2 & $1.2^{*}$ \\
\hline
\end{tabular}

*The large decrease in erosion is connected with problems at the measurement sites.

* Značajano smanjenje erozije povezano je s problemima na lokaciji mjerenja. 
Despite the short duration of our measurements, it is clear that major precipitation events contribute a considerable proportion to annual soil loss. The role of these major precipitation events in soil erosion has been described by Larson et al. (1997), among others.

During the first measurement period, the most erosive precipitation occurred in the week between 5 August and 12 August 2005 (weekly erosive precipitation totalled 1,235.91 $\mathrm{MJ} \cdot \mathrm{mm} \cdot \mathrm{ha}^{-1} \cdot \mathrm{h}^{-1}$; on 11 August 2005 , the maximum 30 -minute precipitation totalled 42.8 $\mathrm{mm}$ and the daily erosive precipitation was $1,110.5 \mathrm{MJ} \cdot \mathrm{mm} \cdot \mathrm{ha}^{-1} \cdot \mathrm{h}^{-1}$; and the erosivity of precipitation was well above the August monthly average $\left[507.8 \mathrm{MJ} \cdot \mathrm{mm} \cdot \mathrm{ha}^{-1} \cdot \mathrm{h}^{-1}\right.$; Petkovšek and Mikoš, 2004] for the Dragonja River Basin). During this week, up to $30 \%$ of the entire annual amount was eroded from the bare soil in the olive grove and up to $24 \%$ from the meadow. In the forest, the proportion of eroded material was correspondingly smaller due to the full foliage of the trees. In the forest with a lower inclination it totalled $15 \%$, and in the forest with a greater inclination the proportion did not rank among the extreme values and was in fact even smaller than the erosion during individual weeks in the cold part of the year, when there were no leaves in the canopies. The importance of foliage relative to soil erosion is clearly evident from these indicators.

Such precipitation caused erosion rills on bare soil in the olive grove. It turned out that the proportion of rill erosion relative to the total of rill and interrill erosion was between 75 and $90 \%$. These proportions roughly matched the findings of Govers and Poesen (1988), who reviewed the literature and concluded that only about $20 \%$ of soil erosion is interrill erosion (Boardman 2006, 75). With the precipitation event described above, interrill erosion was $26.7 \mathrm{t} / \mathrm{ha}$, whereas rill erosion amounted up to $297.8 \mathrm{t} / \mathrm{ha}$.

The measurements showed that the current estimates of erosion in Slovenia, which are primarily based on modelling, are too low (compare Tab. 1 and 2). Only the meadow was an exception, but it is necessary to add that our measurements were taken on an overgrown meadow and so perhaps should more properly be compared with the overgrown surfaces in Tab. 2.

Tab. 2 Estimate of erosion ( $\mathrm{t} /$ ha per year) on various land-use types in Slovenia (Komac and Zorn, 2005; Petan, 2010, 10)

Tab. 2. Procjena erozije ( $t /$ ha godišnje) pri različitim načinima iskorištavanja zemljišta u Sloveniji (Komac $i$ Zorn, 2005; Petan, 2010, 10)

\begin{tabular}{|c|c|c|c|c|c|c|c|}
\hline $\begin{array}{c}\text { Cultivated } \\
\text { fields }\end{array}$ & $\begin{array}{c}\text { Barren } \\
\text { and high- } \\
\text { mountain } \\
\text { areas }\end{array}$ & $\begin{array}{c}\text { Grasslands } \\
\text { (meadows } \\
\text { and pastu- } \\
\text { res) }\end{array}$ & Vineyards & $\begin{array}{c}\text { Forest and } \\
\text { overgrown } \\
\text { surfaces }\end{array}$ & Orchards & $\begin{array}{c}\text { Hop plan- } \\
\text { tations }\end{array}$ & Average \\
\hline 22 & 69 & 5.4 & 28 & 0.43 & 30 & 4.6 & 4.5 \\
\hline
\end{tabular}

\section{Processes in badlands}

Sediment production from steep bare flysch slopes amounted to approximately 85 $\mathrm{kg} / \mathrm{m}^{2}$ per year (Tab. 3), which means that the slope is retreating at approximately 35 $\mathrm{mm}$ to almost $50 \mathrm{~mm}$ per year. The speed of rockwall retreat clearly indicates the great erodibility of flysch rocks. 
During the measurement period, we observed three peaks in sediment production. The primary peak is connected with the alternation of temperatures above and below freezing during the daytime in the colder part of the year. The secondary and tertiary peaks are connected with heavier precipitation in the spring and summer (for more details see Zorn, 2009b).

Tab. 3 Sediment production from steep bare flysch slopes (Zorn, 2009b, 301)

Tab. 3. Produkcija sedimenta na strmim ogoljelim padinama oblikovanim u flišu (Zorn, 2009b, 301)

\begin{tabular}{|c|c|c|}
\hline Measurement period & $\begin{array}{c}\text { Sediment production } \\
\text { (t/ha per year) }\end{array}$ & $\begin{array}{c}\text { Rockwall retreat } \\
\text { (mm/year) }\end{array}$ \\
\hline April 2005-April 2006 & 842.6 & $36.6-49.2$ \\
\hline
\end{tabular}

In the same period, nearly $19 \mathrm{t}$ of debris, or nearly $150 \mathrm{t} /$ ha per year, was moved through the erosion gully in the same badlands (Zorn, 2009b, 311). A similar high movement of material was also measured some years earlier in an erosion gully in the dolomite badlands, where nearly $175 \mathrm{t} /$ ha of dolomite debris was moved per year (Komac, 2003, 31).

\section{APPLICATION-ORIENTED EROSION RESEARCH}

Because policy and management approaches include the use of erosion data, erosion research directly affects the public in term of providing information on this kind of natural hazard and human impacts. "For example, soil loss calculations and geomorphological expertise are used to support soil conservation planning, both through agricultural legislation that defines maximum tolerable soil loss rates ... and local legislation that requires soil erosion controls on many construction sites. To be useful for decision makers, soil erosion models must have simple data requirements, must consider spatial and temporal variability in hydrological and soil erosion processes, and must be applicable to a variety of regions with minimum calibration" (Renschler and Harbor, 2002, 189).

As part of our studies, the following application opportunities for erosion process studies especially came to the fore:

1) To gain data for verification of erosion models;

2) To estimate damage caused by erosion;

3) To raise risk awareness due to erosion hazard; and

4) To improve coastal management.

\section{1) To gain data for verification of erosion models}

In Slovenia, erosion models are primarily used for water-management purposes. For these types of calculations, by far the most common is Gavrilović's equation (Gavrilović, 1962; 1972) and its derivations (Lazarević, 1968; 1985; Pintar et al., 1986), and in recent years the RUSLE model has also been used (e.g., Petkovšek and Mikoš, 2004). The use of the most widespread international erosion model, the USLE, has never gained a foothold in Slovenia. 
The problem with using these models is that they are not calibrated for Slovenian conditions. Such calibration is possible only based on measurements, which have, however, been scant (Komac and Zorn, 2005; Hrvatin et al., 2006). Measurements showed that calculations with erosion models greatly deviated from the measured data (Zorn, 2008) and so their calibration is essential. The fact that the models do not reflect the natural conditions sufficiently well can also be observed behind the dams at hydroelectric plants, where the dam reservoirs are often reduced more rapidly than the models predict due to (overly) rapid sedimentation.

In addition to this, the empirical models mentioned above have the additional problem that they supply data on average annual erosion for conservation planning, even though the measurements show that soil erosion, for example, may be dominated by a few extreme events (Renschler and Harbor, 2002, 197; Zorn, 2008).

\section{2) To estimate damage caused by erosion}

Effects by soil erosion are divided into the following (Soil .., 2010; Renschler and Harbor, 2002, 192):

- On-site effects; for example, the reduction in soil quality that results from the loss of the nutrient-rich upper layers of the soil, and the reduced water-holding capacity of many eroded soils; it affects people that control the source of the erosion; that is, agriculture and also other activities; for example, traffic;

- Off-site effects; for example, the movement of sediment and agricultural pollutants into watercourses, which can lead to sedimentation in watercourses and dams, disruption of lake ecosystems, and contamination of drinking water. In some cases, increased downstream flooding may also occur due to the reduced capacity of eroded soil to absorb water. Off-site impacts affect neighbouring areas where the affected people have little or no influence on the erosion source.

Regardless of all these effects, and regardless of the high values for soil erosion presented above, Slovenian legislation and agricultural practice have not classified soil erosion among natural hazards; for example, the Agricultural Land Act (Zakon o kmetijskih zemljiščih, 1996) and the Protection against Natural and Other Disasters Act (Zakon o varstvu pred naravnimi in drugimi nesrečami, 1994). The consequence of this is that those affected cannot expect assistance from the state like those affected by droughts or floods (e.g., Article 97 of the Protection against Natural and Other Disasters Act, 1994). On the other hand, various documents emphasize that "soil erosion in Slovenia is poorly studied despite the great threat it potentially represents" (Suhadolc, 2005, 14), or that Slovenia has "so far dedicated little attention to soil erosion studies. There are thus no precise data on soil loss due to erosion" (Suhadolc et al., 2010, 50), and the state still has no appreciation of more detailed study of this. Due to this dearth of research, it is also difficult to assess the possible damage, although borrowing data from elsewhere makes it clear that it may be substantial. Thus, in some tropical countries, soil degradation (also including soil erosion) may vary from under $1 \%$ to over $15 \%$ of GDP. On the island of Java (Indonesia) the onsite cost of soil erosion in 1985 was estimated to be approximately $\$ 327$ million, which 
amounted to around $4 \%$ of the total value of dryland crops on Java. At approximately the same time, it was calculated for the Philippines that the damage due to the on-site cost of soil erosion was around $\$ 50.10 /$ ha in nominal prices and $\$ 127.50 /$ ha in shadow prices. It is necessary to add off-site costs to these numbers; for example, those due to sedimentation of dam reservoirs connected with losses in hydroelectric power and so on. It has been calculated for Java that this may result in an annual loss in hydropower up to $\$ 2.7$ million, and all off-site costs may be as high as $\$ 75$ million (Babier, 1995).

If one speaks about sediment yield and the consequent sedimentation of dam reservoirs, even more important than soil erosion is erosion in badlands. Sediment supply from badlands greatly increases sediment delivery and is therefore one of the key factors in water management. According to Staut and Mikoš (2008), the badlands in the Dragonja River Basin extend over $0.37 \%$ of the surface. Despite their relatively small area in the river basin, the badlands contribute the most eroded material. It was determined that in the Red Deer River Basin in Alberta (Canada) badlands constitute $2 \%$ of the river basin surface area and contribute as much as $80 \%$ of annual eroded suspended material (Campbell, 1997 , 265). For the Dragonja River Basin we estimate that sediment delivery from badlands contributes up to $10 \%$ of yearly sediment yield.

\section{3) To raise awareness of erosion hazard}

"Public interest in soil erosion in a particular area depends in large part on the extent to which erosion and its impacts are clearly visible and important over short time scales. In contrast, long-term sheet and interrill erosion are difficult to observe, appear trivial in scale to most casual observers, and are conceptually hard to relate to major impacts either on-site or off-site" (Renschler and Harbor, 2002, 190). This is clearly visible from our soil erosion measurements (Tab. 1) because interrill erosion of approximately $100 \mathrm{t} / \mathrm{ha}$ simply cannot be noticed without measurement, except for somewhat increased sedimentation at the base of the olive grove. In contrast, soil erosion can "easily be observed in the appearance of deep rills and ephemeral gullies on fields (Fig. 2), sediment loaded surface runoff, or gully and stream bank erosion in channels. Extreme events that lead to onsite, short-term yield reduction; major filling or sediment removal operations; or loss of harvest directly affect farm income on a time scale that is relevant to most farmers" (Renschler and Harbor, 2002, 190). Renschler and Harbor $(2002,193)$ observed that it is usually these low-frequency, high-magnitude events that spur public interest in impact assessment, regulation, and management. It is also necessary to be aware that the off-site impacts of erosion are potentially greater, as mentioned above.

In addition to this, measurements can also help define the maximum rate of soil erosion that still allows sustainable agricultural production (Renschler and Harbor, 2002, 195), or, as Lal (1998) put it, "tolerable soil loss".

\section{4) Coastal management}

For coastal management it is also necessary to be aware of erosion processes because (for example) a full "70 per cent of the world's sandy coastline is undergoing net erosion. 


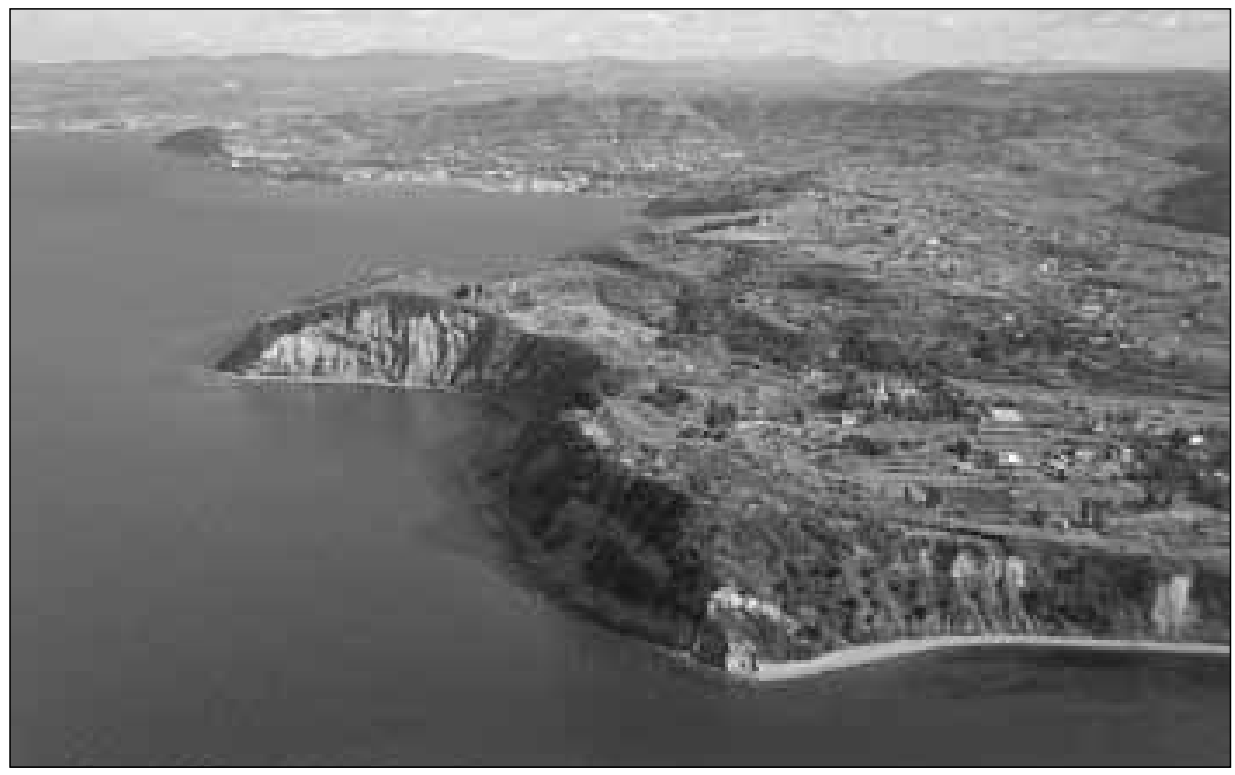

Fig. 8 Flysch cliffs predominate on the Slovenian coast (photo: Marjan Garbajs) Sl. 8. Strmci oblikovani u flišu prevladavaju na slovenskoj obali (fotografirao Marjan Garbajs)

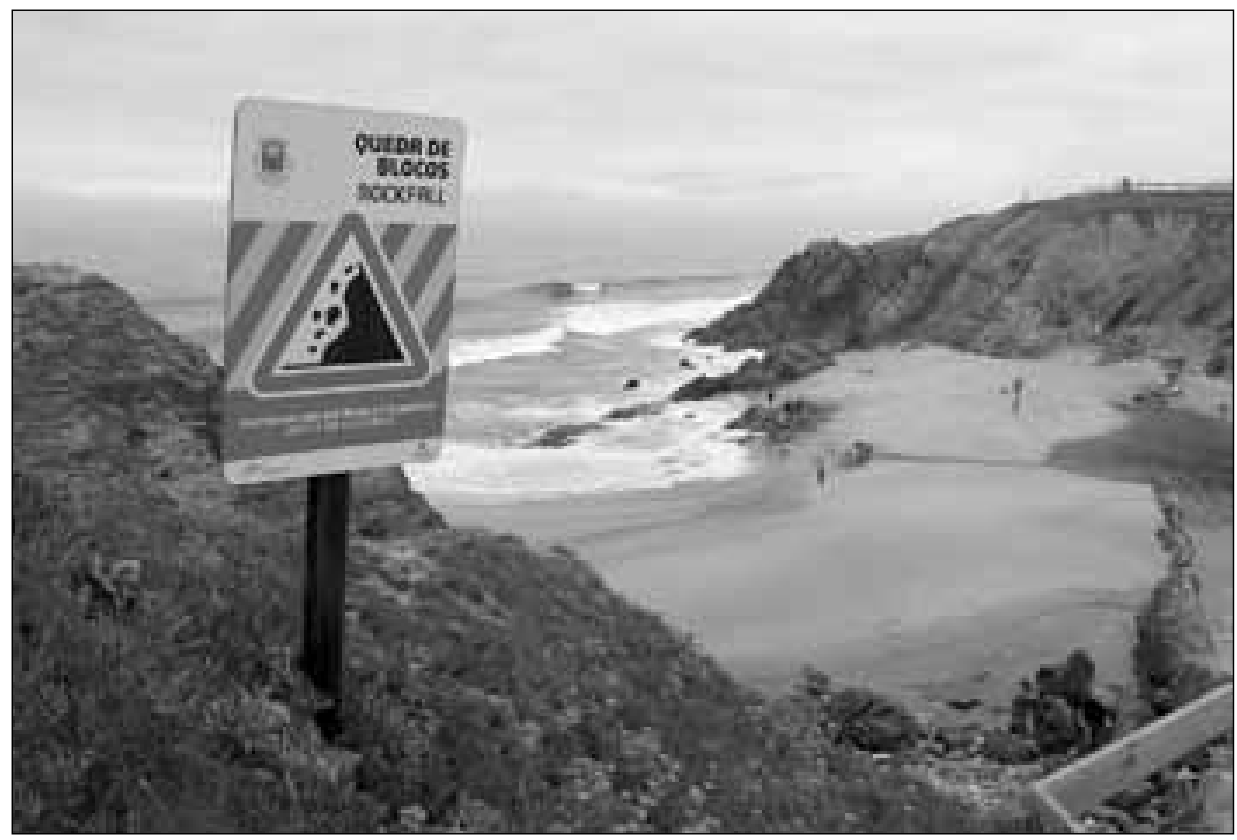

Fig. 9 Experience with rockfalls on the steep shores of the São Pedro de Moel (Portugal) led to a more safety orientated coastal management

Sl. 9. Iskustvo s urušavanjem strme obale São Pedro de Moela (Portugal) rezultiralo je politikom upravljanja priobaljem usmjerenijom na sigurnost ljudi 
As 60 per cent of the global population ... live in the planet's coastal zones, and two-thirds of the world's cities with populations of 2.5 million or more are located in open coast or estuarine locations," according to Spencer (1999, 109), coastal erosion represents "a major environmental issue."

A special problem is represented by cliff coasts (Fig. 8), where rockfalls may threaten lives; for example, as in the Canary Islands in November 2009 (Dawar, 2009; Los Gigantes, 2009). The Slovenian coast also has cliffs in many places and is therefore also shaped by rockfalls. The Slovenian media (e.g., Nevarno ..., 2003) also carry reports of swimmers being injured by falling rock.

The information that we have obtained for steep slopes in badlands thus also enables us to understand the dynamics of processes on Slovenian coastal cliffs. The fact that it is possible to predict what kind of weather conditions will result in more intensive sediment production on such slopes can assist in the safer management of coastal areas.

\section{CONCLUSIONS}

Erosion is a common problem in Europe (Boardman and Poesen, 2006), but has rarely been recognized in some countries (e.g., Slovenia) as an important issue, because erosion (as defined in this article) and its impacts are usually clearly visible only in longterm scale. In Slovenia the low-frequency, high-magnitude events (e.g., mass wasting) usually spur public interest in impact assessment, regulation, and management, while the low-magnitude, high- frequency processes (e.g., soil erosion) remain in shadow.

This is the main reason why the quantification of these processes is needed. The erosion measurements presented above were carried out between 2002 and 2008 on highly erodible bedrock and soil in flysch and dolomite regions of Slovenia. We have shown that such measurements have direct applied value for quantification of processes, verification of erosion models, soil conservation planning, estimation of damage caused by erosion, or to raise risk awareness of erosion hazard.

Soil loss is one of the main eight threats with which soils in the European Union are confronted (Proposal for a Directive ..., 2006, 2). As shown above, it has been poorly studied in Slovenia. Our studies of soil erosion are a good example of scientific knowledge and detailed information that can be directly used by policy and management organizations in terms of providing information on nature and intensity of erosion hazard and human impacts, by using the data in proper erosion models. In Slovenia, erosion models have been primarily used for water-management purposes and only rarely in other fields, such as farming. Measurements showed that the calibration of the models is essential.

The information that we have obtained from badlands also enabled us to understand better the dynamics of processes in them, and also to understand better the filling of dam reservoirs in highly erodible river basins, as well as to study the morphogenesis of flysch coastal cliffs. The fact that it is possible to predict what kind of weather conditions will result in more intensive sediment production in erodible areas can assist in the risk management. 
All these bring us to the basic problem of applied geography/geomorphology, how to convince stakeholders that our knowledge is important for decision making. Renschler and Harbor $(2002,206)$ wrote: "Geomorphologists are well placed to play a significant role in policy discussions and to provide tools and expert opinion that help in the formulation and implementation of policy". However, the reality is all too often different, because those involved do not recognize the applied value of geomorphological studies. Good examples are the studies of erosion processes presented here. Despite intense efforts by those researching them, in Slovenia they are not being applied outside the circle of geomorphologists.

\section{REFERENCES}

Babier, E,.. B., 1995: The Economics of Soil Erosion: Theory, Methodology and Examples. http://www.idrc.ca/ uploads/user-S/10536145400ACF2B4.pdf (10. 11. 2010).

Boardman, J., 2006: Soil erosion science: Reflections on the limitation of current approaches, Catena 68 (2-3), 73-86.

Boardman, J., Poesen, J. (eds.) 2006: Soil Erosion in Europe, Wiley, Chichester.

Campbell, I. A., 1997: Badlands and badland gullies. in: Arid Zone Geomorphology: Process, Form and Change in Drylands (ed. Thomas, D. S. G.), Wiley, Chichester, 261-291.

Dawar, A., 2009: British woman killed in rock fall on Tenerife beach, The Sunday Times (2. 11. 2009). http:// www.timesonline.co.uk/tol/news/uk/article6898665.ece (10. 11. 2010).

Gavrilović, S., 1962: Proračun srednje-godišnje količine nanosa prema potencijalu erozije, Glasnik šumarkog fakulteta 26, 151-168.

Gavrilović, S., 1972: Inženjering o bujičnim tokovima i eroziji, Izgradnja, Beograd.

Govers, G., Poesen, J., 1988: Assessment of the interrill and rill contributions to total soil loss from an upland field plot, Geomorphology 1 (4), 343-354.

Hrvatin, M., Komac, B., Perko, D., Zorn, M., 2006: Slovenia. in: Soil Erosion in Europe (eds. Boardman, J., Poesen, J.), Wiley, Chichester, 297-310.

Komac, B., 2003: Dolomite relief in the Žibrše Hills, Acta geographica Slovenica 43 (2), 7-30.

Komac, M., Zorn, M., 2005: Soil erosion on agricultural land in Slovenia - measurements of rill erosion in the Besnica valley, Acta geographica Slovenica 45 (1), 53-86.

Lal, R., 1998: Agronomic consequences of soil erosion. in: Soil Erosion at Multiple Scales: Principals and Methods for Assessing Causes and Impacts (eds. De Vries, P., Agus, F., Kerr, J. ), CABI Publishers, Wallingford, 149-160.

Larson, W. E., Lindstrom, M. J., Schumacher, T. E., 1997: The role of severe storms in soil erosion: a problem needing consideration, Journal of Soil and Water Conservation 52 (2), 90-95.

Lazarević, R., 1968: Erozija u slivu Gvozdačke reke - prilog metodi za izradu karte erozije, Glasnik srpskog geografskog društva 49 (2), 75-98.

Lazarević, R., 1985: Novi postupak za određivanje koeficijenata erozje (Z). Erozija - stručno-informativni bilten 13, 53-61.

Los Gigantes rock fall, Tenerife Magazine (1. 11. 2009). http://www.tenerifemagazine.com/happenings/2-dead6-trapped-in-los-gigantes-rockfall.htm (10. 11. 2010). 
Lupia-Palmieri, E., 2004: Erosion. in: Encyclopedia of Geomorphology, Vol. 1 (ed. Goudie, A. S.), Routledge, London, 331-336.

Nevarno kopanje ob valečih se skalah, Delo (21. 8. 2003), Ljubljana.

Petan, S., 2010: Meritve in modeliranje erozivnosti padavin kot parametra erozije tal, Ph. D. Theses, Fakulteta za gradbeništvo in geodezijo, Ljubljana.

Petkovšek, G., Mikoš, M., 2004: Estimating the $R$ factor from daily rainfall data in the sub-Mediterranean climate of southwest Slovenia, Hydrological Sciences Journal 49 (5), 869-877.

Petraš, J., Holjević, D., Patrčević, V., 2008: Mjerenje produkcije erozijskog nanosa na istraživačkom poligonu "Abrami" u Istri. in: Savjetovanje: Hidrološka mjerenja i obrada podataka (ed. Ožanić, N.), Građevinski fakultet Sveučilišta u Rijeci, Hrvatsko hidrološko društvo, Rijeka, 190-206.

Pintar, J., Mikoš, M., Verbovšek, V., 1986: Elementi okolju prilagojenega urejanja vodotokov: alternativa utesnjevanju živih naravnih procesov v toge objekte. in: Drugi kongres o vodama Jugoslavije, 2. knjiga (ed. Simonović, S.), Jugoslovensko društvo za odvodnjavanje i navodnjavanje, Beograd, 800-814.

Poesen, J. W. A., Hooke, J. M., 1997: Erosion, flooding and channel management in Mediterranean environments of southern Europe, Progress in Physical Geography 21 (2), 157-199.

Proposal for a Directive of the European Parliament and of the Council Establishing a Framework for the Protection of Soil and Amending Directive 2004/35/EC, COM(2006) 232 final, Brussels. http://ec.europa. eu/environment/soil/pdf/com_2006_0232_en.pdf(10.11.2010).

Renschler, C. S., Harbor, J., 2002: Soil erosion assessment tools from point to regional scales - the role of geomorphologists in land management research and implementation, Geomorphology 47 (2-4), 189-209.

Soil erosion site. http://soilerosion.net/ (10.11. 2010).

Spencer, T., 1999: Coastal erosion. in: Applied Geography: Principles and Practice (ed. Pacione, M.), Routledge, London, 109-123.

Staut, M., Mikoš, M., 2008: Spremembe intenzivnosti erozije v porečju Dragonje v drugi polovici 20. stoletja, Annales: Series historia naturalis 18 (1), .

Suhadolc, M., 2005: Ocena izvajanja konvencije ZN o boju proti dezertifikaciji/degradaciji tal v Sloveniji, The Regional Environmental Center for Central and Eastern Europe, Ljubljana. http:/www.unccd.int/cop/reports/ northmed/national/2006/slovenia-eng.pdf (10. 11. 2010).

Suhadolc, M., Sušnik, A., Lobnik, F., Kajfež-Bogataj, L., Gregorič, G., Bergant, K., 2010: Izzivi Slovenije na področju suš in degredacije tal: uresničevanje ciljev Konvencije ZNo boju proti degradaciji/dezertifikaciji tal (UNCCD), Agencija RS za okolje, Ljubljana. http://meteo.arso.gov.si/uploads/probase/www/agromet/ product/document/sl/IZZIVI_Slovenije_na_podrocju_sus_in_degradacije_tal.pdf(10.11.2010).

Zakon o kmetijskih zemljiščih, Uradni list Republike Slovenije 59/1996, Ljubljana.

Zakon o varstvu pred naravnimi in drugimi nesrečami, Uradni list Republike Slovenije 64/1994, Ljubljana.

Zorn, M., 2008: Erozijski procesi v slovenski Istri, ZRC Publishing, Ljubljana.

Zorn, M., 2009a: Erosion processes in Slovene Istria - part 1: Soil erosion, Acta geographica Slovenica 49 (1), 39-87.

Zorn, M., 2009b: Erosion processes in Slovene Istria - part 2: Badlands, Acta geographica Slovenica 49 (2), 291-341.

Received (Primljeno): 2011 - 01 - 15

Accepted (Prihvaćeno): 2011 - 10 - 21 
Hrvatski geografski glasnik 73/2 (2011.)

\author{
Matija Zorn \\ Anton Melik Geographical Institute \\ Scientific Research Centre of the Slovenian \\ Academy of Sciences and Arts \\ Gosposka ulica 13 \\ SI - 1000 Ljubljana \\ matija.zorn@zrc-sazu.si
}

Blaž Komac

Anton Melik Geographical Institute Scientific Research Centre of the Slovenian Academy of Sciences and Arts

Gosposka ulica 13

SI - 1000 Ljubljana

blaz.komac@zrc-sazu.si 